\title{
How Franchisors Describe Their Ideal Entrepreneurial Franchisee
}

Jacques Boulay, ESSCA School of Management, LUNAM Université, France Valentina Stan, ESSCA School of Management, LUNAM Université, France

\begin{abstract}
This article has two main objectives: first, to identify the various entrepreneurial profiles of the ideal franchisee, as perceived by franchisors, and second, to describe and compare each profile on the basis of system characteristics. Qualitative research of franchisors is coupled with analyses of data collected from 90 franchise systems. This procedure offers strong sequential evidence in that the results of the first method inform the second-stage sampling and instrumentation (Greene et al., 1989). The study reveals three main entrepreneurial profiles of prospective franchisees system developer, in-store craftsperson, and opportunistic investor. It also establishes that the term of the franchise agreement and the level of system plurality are two factors on which entrepreneurial profiles differ. These results offer strong support for franchisors in their selection strategy of future franchise partners.
\end{abstract}

Keywords: Franchising; Franchisor; Franchisee; Entrepreneur; Entrepreneurship; Franchisor-Franchisee Relationships; Entrepreneurial Orientation

\section{INTRODUCTION}

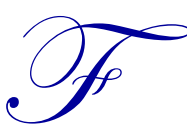

ranchising is a major feature of the modern retail landscape. In the United States, it supports 18 million jobs that contribute to more than \$2.1 trillion of economic output (International Franchise Association, 2012). China has developed more than 4,500 franchise systems and 400,000 franchise stores in less than 20 years (China Chain Store \& Franchise Association, 2012). In Europe, France is the most prominent franchise market, with roughly 60,000 franchise outlets, which produce an estimated turnover of $€ 50$ billion. As franchising is still growing worldwide as a way of doing business, this trend calls for further research into the phenomenon and its actors.

Franchising links two business partners - the franchisor and the franchisee. The franchisor grants-in exchange for an entry fees and royalties, usually based on the sales of the franchised unit - a franchisee the right to market the franchise's goods or services under its brand name. If there is little doubt that the franchisor is an entrepreneur, recent franchise research still questions the entrepreneurial status of franchisees (Ketchen et al., 2011). A franchisee also invests his own money in the franchise and enjoys some autonomy in how to run it, but he is not the initiator of the business opportunity and his objective may not be to grow the business, as an entrepreneur prefers, but rather just to make a living. Empirical studies also indicate significant variation in entrepreneurial behaviours among franchisees (Fenwick and Stronbom, 1998; Grünhagen and Mittelstaedt, 2005; Hing, 1995; Tuunanen and Hyrsky, 2001). This suggests that various entrepreneurial profiles of franchisees can coexist within a same chain.

With this research, we contribute to this debate by investigating entrepreneurial profiles of the ideal franchisee that franchisors are looking for. Our aim is to help franchisors select their franchise partners - a key success factor for chain operators (Jambulingam and Nevin, 1999).

This article begins by examining franchise literature related to franchisees and entrepreneurship. After, we present the result of an empirical research among franchisors, which reveals three main entrepreneurial profiles of ideal franchisee. This research also allows for the development of a series of hypotheses aimed at verifying whether 
these entrepreneurial profiles differ based on the franchise chain characteristics (age and size of the system, term of franchise agreement, level of plurality). The subsequent section is dedicated to presenting and discussing the results of the test of the hypothesis. Finally, we draw from our results a series of academic contributions, discuss implications for franchisors, and conclude with some research limitations and guidelines.

\section{ARE FRANCHISEES ENTREPRENEURS? LITERATURE REVIEW}

Are franchisees entrepreneurs? Based on an analysis of the existing empirical literature, the answer to this question can be organized along three main perspectives - personality traits, autonomy vs. dependence, and entrepreneurial orientation.

\section{The Personality Traits Perspective}

One of the first studies on the entrepreneurial traits of franchisees describes the ideal franchisee as someone who is "energetic, responsible, and cooperative: It is not necessary that he be overly intelligent [sic], but he definitely should be the type who is willing to take a risk" (Eden et al., 1976, p. 42).

Though it appears as a key trait of the franchisee entrepreneur, risk-taking is ignored by Mesconi and Montanari (1981) in their investigation of the relationship between six personality traits of entrepreneursachievement, autonomy, dominance, endurance, order, and locus of control - and the type of entrepreneurial venture (independent vs. franchise). They find no difference between the two types of ventures in the achievement, autonomy, dominance, or locus of control characteristics. However, endurance and order appear to vary significantly with the type of business, such that franchisees are less enduring and orderly than independent business owners. They suggest that the independent owners' higher level of perseverance to succeed contribute to that result.

Following up on this distinction, Knight (1984) compared the personal characteristics of 105 franchisees and 102 independent entrepreneurs. He found no difference in their desire to succeed or willingness to work hard. Moreover, he refutes the idea that the risk of failure is lower for franchisees. He also argues that independent ventures are more self-reliant than franchisees.

Later, in an explicit examination of why people choose to join a franchise rather than start an independent business, Withane (1991) asked 150 franchisees to rank the importance of seven personal characteristics for the success of a franchisee. His results are need for achievement, initiative, self-reliance, competitiveness, internal control, autonomy, and risk-taking; but when the same respondents provide self-assessments of how they manifest each characteristic, the ranking is quite different, with risk taking, competition, and self-reliance as the top three characteristics. Furthermore, 68 percent consider operating an independent venture more challenging and entrepreneurial than operating a franchise. That is, if franchisees regard franchising as a less risky option, they see themselves as risk takers.

More recently, comparing 77 franchisees with 93 small business owners and 32 entrepreneurs, Anderson et al. (1992) question whether franchisees are real entrepreneurs. They show that franchisees do not differ from real entrepreneurs when it comes to self-assurance, decisiveness, need for power, or need for financial reward, but they observe differences in terms of achievement motivation, supervisory ability, initiative, and self-actualization, for which entrepreneurs score higher than franchisees. They also observe that franchisees have a greater need for security.

The personality traits studies therefore assert some differences across (future) franchisees' entrepreneurial profiles. They also raise questions about the balance between autonomy and dependence in the franchise relationship. 


\section{The Autonomy vs. Dependence Perspective}

As observed by Stanworth (1995), franchisee falls somewhat between the independent small business owner and "a managed outlet featuring in the corporate marketing activity of another independent business, that of the franchisor (Stanworth, 1995, p. 162)".

Peterson and Dant (1990) indicate that greater independence is one of the main reasons for becoming a franchisee, and of the Canadian franchisees questioned by Knight (1986), 92 percent have identified independence as one of the key benefits of owning a franchise. However, other empirical studies indicate that entrepreneurs who prefer to set up their own businesses regard franchisees more as employees of the franchisor than as independent business owners (Paswan and Johns, 2007). The rationale behind this assertion is the franchisee's obligations as imposed by the contractual agreement. Related to location, sales packages, customer service, and so forth, these obligations would limit the franchisee's independence.

Nevertheless, it has been observed that a same franchisee can simultaneously demonstrate high levels of dependence and high levels of autonomy (Dant and Gundlach, 1998). First, the franchisee is responsible for adapting the franchise concept to his or her local market conditions. On a daily basis, he or she has some room to manoeuver. While abiding by the directives given by the chain operator, she is often on her own when it comes to recruiting sales personnel, displaying novelties, fixing prices or advertising locally. In some systems, franchisees can even be encouraged to innovate as it allows for the emergence of new practices that will benefit the system as a whole, including the company outlets (Bradach, 1998; Kaufmann and Eroglu, 1999; Lindblom et al., 2008).

\section{The Entrepreneurial Orientation Perspective}

Brannen encapsulates very well the issue of innovation in franchising when she describes franchisees as imitative entrepreneurs; that is, entrepreneurs whose role is to disseminate innovations once they have been proven useful by initiating entrepreneurs (the franchisors). Innovativeness is one of the key dimensions of the measure of the entrepreneurial orientation of individuals with ability to take risks, responsiveness, competitiveness and autonomy (Lumpkin and Dess, 1996).

Fenwick and Stronbom (1998) were among the first ones to address the issue through a survey of 36 franchisees of a single retail franchise system. They found a positive relationship between franchisees' entrepreneurial orientation and annual sales growth.

Tuunanen and Hyrsky (2001) followed up on this result by exploring franchisees' entrepreneurial characteristics. They found that franchisees see themselves as customer-oriented and eager to take responsibility for their actions; but despite their sense of self-confidence, they seem unwilling to expand or diversify. Tuunanen and Hyrsky explain this pattern by a risk-aversion attitude.

More recently, Dada et al. (2011) studied the organizational antecedents and performance outcomes for the franchisees of 95 franchisors. Their results reveal a positive link between franchisees' entrepreneurial orientation and both financial and non-financial performance outcomes. They also observe that franchise systems that encourage entrepreneurial orientation through franchisors' support or contract clauses lead to a higher level of entrepreneurial orientation among franchisees.

\section{Limitations of Existing Studies and Research Objectives}

When one looks at the literature background on the subject of entrepreneurship applied to the case of (future) franchisees, one can admit the lack of consensus when it comes to answering the question, "Are franchisees entrepreneurs?" The answer is alternatively "yes, no or maybe so", in line with what Ketchen et al. (2011) recently observed. Among the various explanations, first, most authors do not question the entrepreneurial proclivity of franchisees but rather take it for granted. They also deal with "a" franchisee entrepreneur, though the literature in entrepreneurship suggests variety in the entrepreneurial profiles of individuals. 
Second, the existing literature relies on various measures of the concept of entrepreneurship applied to franchisees. It includes entrepreneurial personality (Hing, 1995), entrepreneurial tendencies (Fenwick and Stronbom, 1998), entrepreneurial characteristics (Tuunanen and Hyrsky, 2001), entrepreneurship motivation (Grünhagen and Mittelstaedt, 2005), and entrepreneurial orientation (Dada and Watson, 2012). This variety limits the generalizability of their results. Moreover, these results regularly contradict one another. For example, whereas Withane (1991) indicates that franchisees self-assess themselves as risk-takers, Tuunanen and Hirsky (2001) conclude they are riskaverse. Further analysis should then clearly delineate what franchisors mean by the term "entrepreneur" when they say that they are looking for entrepreneurial partners.

Another limitation is that most research deals with actual franchisees rather than future/ideal ones. This approach introduces a bias because actual franchisees regard themselves as a certain type of entrepreneur, more so than they would have considered themselves before they joined the franchise system (Withane, 1991).

Last but not least, typologies of franchisee entrepreneurs are scarce and they are mainly based on existing typologies from the entrepreneurship field. Also, with the exception of Fenwick and Stronbom (1998), one can observe a lack of characterization of the franchisee entrepreneur. A better characterization would offer the possibility for chain operators to better fine tune their selection process.

With the present study, we aim at going beyond these limitations by analyzing the entrepreneurial profiles of the ideal franchisee that franchisors are seeking. We also develop and test a series of hypothesis that pose that a franchisee entrepreneurial profile could differ based on the franchise system characteristics.

\section{ENTREPRENEURIAL PROFILES OF IDEAL FRANCHISEE}

The first step is to identify if different entrepreneurial profiles of an ideal franchisee exist, so we conducted a qualitative survey among a sample of franchisors. Through a manual content analysis, coupled with a cluster analysis of their comments, we identified three main entrepreneurial profiles. Also based on these interviews with franchisors, we developed a series of hypotheses to verify whether these entrepreneurial profiles are different based on the franchise chain characteristics (age and size of the system, term of franchise agreement, level of plurality).

\section{Typology of Entrepreneurial Profiles}

As shown in Table 1, our sample comprised 14 franchise systems at different stages of development and from various sizes and sectors. In each system, we interviewed the manager in charge of selecting franchisees. Each interview comprised three parts. First, we asked about how the system recruited franchisees, from the promotional package to the final selection. Second, we offered an open-ended question about the "ideal" franchisee sought by the system and how this profile might evolve over time. Third, the final section pertained to the franchisors' preferred entrepreneurial skills when recruiting a new franchisee.

We stopped the interviews when we had reached informational redundancy and believed that gathering input from additional franchisors would not lead to new ideas (Bowen, 2008). Our total number of interviews is similar to the totals in other recent qualitative franchise research (e.g., Dada et al., 2011; Brookes and Altinay, 2011; Vaishnav and Altinay, 2009; Weaven and Frazer, 2007). 
Table 1: Qualitative Survey Sample Characteristics ${ }^{1}$

\begin{tabular}{|l|l|c|c|}
\hline \multicolumn{1}{|c|}{ Sector } & Age of Franchise System & Number of Franchised Units \\
\hline 1 & Non-food retailing & $>20$ years & $>200$ \\
\hline 2 & Personal services & $>20$ years & $>200$ \\
\hline 3 & Personal services & $>20$ years & $10-20$ \\
\hline 4 & Restaurant & $10-20$ years & $50-100$ \\
\hline 5 & Restaurant & $>20$ years & $100-150$ \\
\hline 6 & Food retailing & 10 years & $50-100$ \\
\hline 7 & Restaurant & $>20$ years & $200-300$ \\
\hline 8 & Home / Leisure & $>20$ years & $50-100$ \\
\hline 9 & Restaurant & $5-10$ years & $10-20$ \\
\hline 10 & Home / Leisure & $10-20$ years & $100-150$ \\
\hline 11 & Home / Leisure & $>20$ years & $50-100$ \\
\hline 12 & Home / Leisure & $5-10$ years & $10-20$ \\
\hline 13 & Personal services & $>20$ years & $50-100$ \\
\hline 14 & Home / Leisure & & \\
\hline
\end{tabular}

Each interview lasted 45 to 60 minutes and was recorded and fully transcribed. We followed Gauzente's (2002) methodology which has been proven effective for analyzing qualitative data in franchise research. We first conducted a manual content analysis of the corpus by dividing and categorizing it according to key themes. In parallel, a statistical textual analysis was performed using the Alceste lexical analysis software (Gauzente, 2002). By combining both methods, we achieved triangulation and could confirm our findings (Miles and Huberman, 1994). With Alceste, the objective is to quantify text to extract the strongest meaningful structures and then order them in a significant manner through cluster analysis. Alceste relies on the assumption that "language levels and text structures can be inferred from recurrent distributions of words" (Gauzente, 2002, p. 6). After analyzing the vocabulary and dividing the corpus, Alceste performs a top-down classification. Using co-occurrences (cluster analysis), it extracts sequences of words or sentences that are representative of the corpus (context units). These units are classified and each class can then be examined according to its class profile, which consists of a list of the most characteristic words and context units. The lexico-metric analysis of our interviews revealed three entrepreneurial profiles of ideal franchisee as shown in Table 2.

Table 2: Entrepreneurial Profiles of Ideal Franchisee

\begin{tabular}{|c|c|c|c|}
\hline Class & System Developer & In-Store Craftsperson & Opportunistic Investor \\
\hline Weight (\%) & $32.75 \%$ of context units & $37.99 \%$ of context units & $29.26 \%$ of context units \\
\hline Interpretation & $\begin{array}{l}\text { The desire to develop } \\
\text { professionally through } \\
\text { entrepreneurship/business } \\
\text { creation: Seeks independence } \\
\text { and autonomy, willing to } \\
\text { develop with and within the } \\
\text { network }\end{array}$ & $\begin{array}{l}\text { The desire to set up own } \\
\text { business by opening a retail } \\
\text { outlet; looking for a second } \\
\text { career, focusing on customer } \\
\text { relations and involvement in the } \\
\text { local environment }\end{array}$ & $\begin{array}{l}\text { The desire to earn more by } \\
\text { accumulating more resources; in } \\
\text { search of the best opportunities } \\
\text { (returns on investment) in the } \\
\text { market and ready to switch } \\
\text { brands if necessary }\end{array}$ \\
\hline $\begin{array}{l}\text { Examples of specific } \\
\text { vocabulary }\end{array}$ & $\begin{array}{l}\text { Independent autonomy } \\
\text { Undertake } \\
\text { Entrepreneur } \\
\text { Create } \\
\text { Entrepreneurship }\end{array}$ & $\begin{array}{l}\text { Store } \\
\text { Set up } \\
\text { In business } \\
\text { Decline } \\
\text { Business } \\
\end{array}$ & $\begin{array}{l}\text { Earn [money] } \\
\text { System } \\
\text { Get on } \\
\text { Opportunistic } \\
\text { First } \\
\end{array}$ \\
\hline
\end{tabular}

Franchisors look for entrepreneurial profiles when describing their ideal franchisee: "If he isn't an entrepreneur, he won't be selected"; "It's crucial - you either have this entrepreneurial spirit inside you or you don't"; "If you don't recruit a candidate with an entrepreneurial spirit, you're almost doomed from the start"; and "She must be an entrepreneur; it's essential."

The system-developer (SD) profile describes an ideal franchisee who will want first and foremost to develop professionally by creating his or her own business. Seeking some independence in the job, the ideal

\footnotetext{
${ }^{1}$ In order to preserve the respondents' anonymity, all descriptive information appears in the form of classes or minima. 
franchisee is a developer, ready to take on challenges, such as moving into a difficult area or being part of the development of a new concept. This profile is particularly in demand when the network needs to grow rapidly. The ability to develop new markets (e.g., through strong sales skills) is especially stressed by franchisors.

The in-store craftsperson (ISC) profile describes the ideal franchisee as an "artisan", echoing Smith's (1967) "craftsman entrepreneur" who will wish to exercise tight control over his or her activity. His or her ambition is first to make a living from the business. We call this profile in-store craftsperson because the qualifiers tend to stress a position within his or her local environment, passion for the job, and the importance of human relationships.

The third profile we identified is the opportunistic investor (OI) profile. This profile describes the ideal franchisee as someone who will be proactive and ready to invest in the growth of the system from a financial perspective. He will always look for the best opportunities in the market. This profile has great attraction for some systems while others avoid it at all costs. This last profile has appeared previously in franchise literature though it has been described as a person motivated more by long-term financial returns rather than by the desire to fulfill entrepreneurial ambitions (Grünhagen and Mittelstaedt, 2005).

Besides the existence of different entrepreneurial profiles, our interviews also suggest that if a franchise system looks for a dominant profile when describing its ideal franchisee, this profile can evolve; thus the importance of analyzing under what conditions this evolution can take place.

\section{Do Characteristics of Franchise Chains Differentiate the Entrepreneurial Profile? Hypothesis Development}

We retained four variables to characterize each system according to the entrepreneurial profiles of its ideal franchisee-age and size of the system, term of the franchise agreement, and level of plurality-as previous research has shown that they bear some discriminatory power for explaining franchise performance (Perrigot et al., 2009; Dant et al., 2008).

System Age

Our interviews suggest that a young system, which has to go fast to install its brand name on the market, will rather focus on the SD profile because they "have the energy, they are real business-builders, and they are people who push you forward and help you to develop the concept". The ISC profile should be more attractive for systems that are in a more mature phase of their life cycle. As the brand is well established, it will offer more security to future franchise partners. The ISC is more focused on his or her unit and is willing to make a living from it, with less expansionary visions than the SD profile - "She will tend to stay at her business" and "spend time in his shop". By attracting ISC, the franchisor also wants to limit the risks involved with the SD profile which, at some point, could undermine the franchise concept - "The main thing is that she can see that she might soon be able to build on what she has learned and that in a few months or years her expertise will be better than yours" and "...he wants to take our place". The OI profile seems to be the ideal profile for older networks in which business opportunities are more limited (the territorial coverage by the brand is already high and the business opportunities are becoming rare for new franchisees; joining the brand may then be more expensive). We then suppose that:

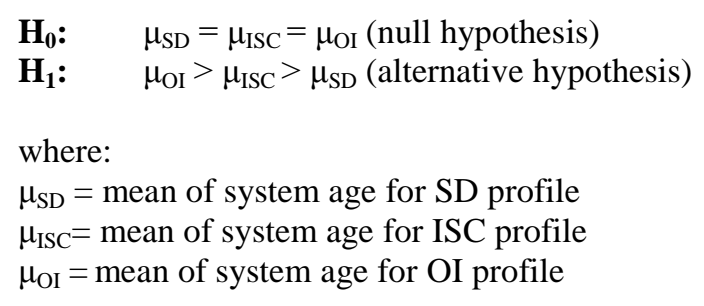

System Size

If it is more costly to join a mature franchise system, as the number of business opportunities within the system has declined along its expansion, one could pose that bigger systems are also the older ones and that the 
same type of hypothesis as previously could then be made (that is, OI > ISC > SD in terms of system size). Actually, two arguments have to be made when it comes to the size of the system. The first one is that franchising has, over the past decade, become a very successful way of expanding for chain operators. The second one is that the majority of new systems can be found in the service sector, which usually implies (except in the restaurant and lodging industry) lower levels of investments than in the product sector. As competition is becoming fierce, it is not unusual to observe systems still in their development stage with a high number of franchise units. This phenomenon has been reinforced by multi-unit franchising (Hussain and Windsperger, 2011). As the SD profile allows for faster development according to some of the franchisors we met ("you need people who are pioneers, people who, when faced with a refusal from a local council or a lobby ..., you know, we need a 'can-do' type of guy"), it could be expected that they will be found in systems with a high number of units. Systems requiring more financial resources could have more difficulty in attracting future franchisees (the OI type). This could also mean that they would be of a lower size (in terms of number of franchise units alone). ISC should fit somewhere in between in terms of system size. As we said before, this profile should be attractive for chain operators looking for stable partners. This leads us to pose:

$\mathbf{H}_{0}: \quad \mu_{\mathrm{SD}}=\mu_{\mathrm{ISC}}=\mu_{\mathrm{OI}}$

$\mathbf{H}_{1}: \quad \mu_{\mathrm{SD}}>\mu_{\mathrm{ISC}}>\mu_{\mathrm{OI}}$

where:

$\mu_{\mathrm{SD}}=$ mean of system size for SD profile

$\mu_{\mathrm{ISC}}=$ mean of system size for ISC profile

$\mu_{\mathrm{OI}}=$ mean of system size for OI profile

\section{Term of Contract}

The franchisor-franchisee relationship is based on a fixed-term agreement. As said before, SD profile should be of particular interest to franchise systems in the phase of development. Nevertheless, this profile represents a potential threat. By being very active in the development of the chain, SD may, at one point, leave the system to open another chain based on the expertise they will have developed. The franchisor looking for this profile should then be careful of not locking himself in a too long-term relationship.

In parallel, long-term agreements are usually found in sectors for which breakeven points occur after a long period of running the business due to the fact that the total investment in these sectors is higher. Contracts can go up to 10-15 years in the restaurant or lodging industry. We can thus anticipate that they are more inclined to seek OI.

As for the ISC profile, franchisors perceive it as a more stable and loyal one within the chain. This profile often comes to franchising after a previous work experience and to make a living. They are looking for stability in the relationship though they do not need contracts as long as the one that would be offered to OI as the investment to recover is lower. We then pose:

$\mathbf{H}_{\mathbf{0}}: \quad \mu_{\mathrm{SD}}=\mu_{\mathrm{ISC}}=\mu_{\mathrm{OI}}$

$\mathbf{H}_{1}: \quad \mu_{\mathrm{OI}}>\mu_{\mathrm{ISC}}>\mu_{\mathrm{SD}}$

where:

$\mu_{\mathrm{SD}}=$ mean of term of contract for SD profile

$\mu_{\mathrm{ISC}}=$ mean of term of contract for ISC profile

$\mu_{\mathrm{OI}}=$ mean of term of contract for OI profile

\section{System Plurality}

The level of system plurality - that is, the percentage of franchised units within a chain - depends on various factors. Among them, transaction cost theory explains that the level of specific investments required to join a chain has an impact on the capacity of the franchisor to attract future franchisees (Dant, 1996). Indeed, the latter have more at stake when they join such a chain, especially if the brand is not well established. If the chain is not 
successful, they will have difficulty recovering their investment or reorienting it in another business. As we said before-that OI is a profile that should be of interest to systems for which the total investment is higher-one can make the hypothesis that such systems will have more difficulty at attracting franchisees and would then rely more on company-owned outlets to develop. Following the same line of argument, as we have posed earlier-that franchising was a viable option to expand rapidly and that SD profiles would fuel a more rapid expansion-SD profiles should be found in systems with a higher number of franchised units.

$\mathbf{H}_{\mathbf{0}}: \quad \mu_{\mathrm{SD}}=\mu_{\mathrm{ISC}}=\mu_{\mathrm{OI}}$

$\mathbf{H}_{1}: \quad \mu_{\mathrm{SD}}>\mu_{\mathrm{ISC}}>\mu_{\mathrm{OI}}$

where:

$\mu_{\mathrm{SD}}=$ mean rate of plurality for SD profile

$\mu_{\mathrm{ISC}}=$ mean rate of plurality for ISC profile

$\mu_{\mathrm{OI}}=$ mean rate of plurality for OI profile

\section{TEST OF HYPOTHESIS}

\section{Sample and Survey Measures}

To test our hypothesis, we used a sample of franchise systems drawn from the 2010 French Franchise Federation (FFF) directory. Franchise directories often serve as a source of data; they provide useful, easily accessible information in a convenient format (Barthelemy, 2008). Although not all franchise systems are members of the FFF, FFF members represent roughly half of all franchisees in the country. One hundred thirteen of the 132 FFF members provide a description of their ideal franchisee. However, 23 of these descriptions refer mainly to technical skills or professional or technical qualifications, so we excluded them from the final sample. The final sample size of 90 is in line with what usually can be observed in studies that rely on the franchisor's perspective (e.g., Bercovitz, 2003; Garg et al., 2005).

In the first stage, each researcher analyzed all 90 system descriptions of their ideal franchisee and linked it to one of the three entrepreneurial profiles identified in the previous stage of the research (SD, ISC, OI). Specifically, we identified from the corpus that collated the descriptions of ideal franchisees by FFF franchisors, the main features of all three classes as they emerged from our lexicographic analysis (Table 2). In the next stage, we compared the results of the classification carried out by each researcher. Following a discussion, we established a stable classification - 36 networks refer to the SD profile, 38 networks refer to the ISC profile, and 16 networks refer to the OI profile.

As it was not always possible to obtain full data for each network, our variable samples are of different sizes.

The age of the franchise system is the number of years since it opened its first franchised outlet. The term of the franchise agreement is expressed in years. The size of the network is the total number of franchised stores. The level of plurality is the percentage of franchised units in the system. The ideal franchisee entrepreneurial profile is a nominal scale.

To validate our hypothesis, we first use the ANOVA. Next, the significant ANOVA is allowed to mount the Scheffe's multiple comparison tests to distinguish exactly which profiles' means were statistically different from each other.

Table 3 contains the descriptive statistics for each profile and the results of both the ANOVAs and Scheffe's paired comparisons. 


\section{RESULTS}

\section{Network Age}

As we have already indicated, our interviews suggest that a young system will prefer SD and ISC profile and OI are pursued more by older ones.

The descriptive statistics is in line with this conclusion: franchisors seeking SD or ISC tend to be younger than networks recruiting OI (15.9 and 18.1 versus 20.2).

Based on data observed from the samples, the ANOVA shows that there is no significant difference between the three profiles on the population with regard to the age of the network ( $p$-value $=0.47$ ).

Finally we conserve the hypothesis of equality of means $\left(\mathrm{H}_{0}\right)$ and thus the network age cannot differentiate the entrepreneurial profiles of prospective franchisees.

\section{Network Size}

The 14 interviews led us to the conclusion that franchise chains looking for SD and ISC are of a bigger size than franchise chains looking for OI profile. This understanding is in line with the results of the descriptive statistics (111 and 95 franchised units versus 83 units).

As with the previous variable, the result of ANOVA shows that there is no significant difference between the mean network size of the three profiles on the population ( $\mathrm{p}$-value $=0.6$ ).

Therefore, we conserve the hypothesis of equality of means $\left(\mathrm{H}_{0}\right)$ and thus the size of the network cannot differentiate the entrepreneurial profiles of prospective franchisees.

\section{Term of Contract}

As shown in our interviews, franchise chains looking for SD should offer shorter term agreements than franchise chains looking for ISC and OI profiles. As expected, the descriptive statistics show that the terms of franchise agreements tend to be shorter, on average, for SD (5.83 years) compared to ISC (6.82) and OI (7.44).

This result can be explained by the fact that OI profiles need more time to recover their investment while ISCs' objective is to make a living off of their partnership with the franchisor, thus they are eager to develop a good relationship.

Based on data observed from the samples, the ANOVA shows that one cannot conserve the hypothesis of equality of means ( $p$-value $=0.02$ ), so at least one of the means is different. Scheffe's paired comparison shows that the mean of OI profile is significantly higher than SD profile ( $\mathrm{p}$-value $=0.04$ ), but no significant difference is observed between ISC and SD ( $\mathrm{p}$-value $=0.13$ ) and between ISC and OI ( $\mathrm{p}$-value $=0.61$ ). Hypothesis $\mathrm{H}_{1}$ is then partially verified. 


\begin{tabular}{|c|c|c|c|c|c|c|c|}
\hline Variables & Profile & $\mathbf{N}$ & Mean & SD & $\mathbf{F}$ & $p$-value & Scheffe's paired comparisons \\
\hline \multirow[t]{3}{*}{ Network age } & SD & 34 & 15.94 & 11.56 & 0.76 (df: 2,85$)$ & 0.47 & \\
\hline & OI & 16 & 20.19 & 10.80 & & & - \\
\hline & ISC & 38 & 18.13 & 12.11 & & & \\
\hline \multirow[t]{3}{*}{ Network size $(\mathrm{H} 2)$} & SD & 35 & 111.17 & 104.28 & 0.51 (df: 2,84$)$ & 0.60 & \\
\hline & $\mathrm{OI}$ & 15 & 82.60 & 110.96 & & & - \\
\hline & ISC & 37 & 94.73 & 83.83 & & & \\
\hline \multirow[t]{4}{*}{ Term of contract } & SD & 36 & 5.83 & 1.75 & 3.88 (df: 2,87$)$ & 0.02 & Based on data observed from the samples, \\
\hline & OI & 16 & 7.44 & 3.22 & & & OI significantly higher than SD profile, \\
\hline & ISC & 38 & 6.82 & 1.74 & & & but no significant difference between \\
\hline & & & & & & & ISC and the others profiles \\
\hline \multirow[t]{4}{*}{ Level of plurality } & SD & 34 & 0.81 & 0.27 & 4.74 (df: 2,83$)$ & $\mathbf{0 . 0 1}$ & Based on data observed from the samples, \\
\hline & OI & 15 & 0.55 & 0.31 & & & SD significantly higher than OI profile, \\
\hline & ISC & 37 & 0.67 & 0.29 & & & but no significant difference between \\
\hline & & & & & & & ISC and the others profiles \\
\hline
\end{tabular}

Significance level: $\alpha=0.05$ 


\section{Level of Plurality}

The descriptive statistics indicate that the level of system plurality is higher for a system looking for SD than for systems looking for ISC or OI profiles ( $81 \%$ versus $67 \%$ and $55 \%$ ).

Based on data observed from the samples, the ANOVA shows that Hypothesis $\mathrm{H}_{0}$ cannot be conserved (pvalue $=0.01$ ), so at least one of the means is different.

Scheffe's paired comparison shows that the mean of SD profile is significantly higher than OI profile (pvalue $=0.02$ ), but no significant difference between ISC and SD ( $\mathrm{p}$-value $=0.13$ ) and between ISC and OI ( $\mathrm{p}$-value $=0.39$ ). Hypothesis $\mathrm{H}_{1}$ has been partially verified.

Franchising is considered a viable option to expand rapidly, even for young networks, which may explain why SD is the profile that most plural systems seek.

\section{CONCLUSION}

Our results offer three main contributions to franchising literature. First, we expanded the existing corpus of research about entrepreneurship and franchising by identifying a typology of entrepreneurial profiles of ideal franchisees. Previous studies have examined the entrepreneurial proclivity of actual franchisees, but most of them assumed that all franchisees are of the same entrepreneurial type. We show that there are not one, but several entrepreneurial profiles - system developers, in-store craftspeople, and opportunistic investors.

Second, to the best of our knowledge, this research is among the first ones to focus on future franchisees, not actual ones. That focus makes a difference as perceptions about whether franchisees are "real" entrepreneurs differ depending on whether they sit in or outside the franchise system (Withane, 1991). By surveying franchisors rather than franchisees, we also complement a recent orientation in the field (e.g., Dada et al., 2011).

Third, using system characteristics, we aimed at identifying the conditions in which a profile better fits within the franchise system.

Finally, from a methodological standpoint, we linked qualitative and quantitative approaches and thus followed Greene et al.'s (1989) recommendation. This procedure offers strong sequential evidence in that the results of the first method inform the second-stage sampling and instrumentation. By combining these methods in the design and analysis phases, our study more clearly elaborates an original framework that offers a better understanding of the franchise phenomenon (Rossman and Wilson, 1998; Waysman and Savaya, 1997).

Of course, the selection of a specific profile will depend on many factors, but our research suggests that the terms of the franchise agreement and the level of plurality can serve as signals to attract specific profiles. The longer the term, the more future franchisees may feel trapped, though it also reassures OI in systems that demand high levels of investment. In turn, franchisors should fine-tune the length of the legal agreement they propose to ensure it functions effectively as a mechanism to attract the "right" entrepreneurial profile. Simultaneously, the level of plurality also can serve as a signal to attract a specific profile as it suggests the level of business opportunities within the same system for future franchisees.

The main limitations of this research are twofold. Franchisors use franchise directories to attract future franchisees, so some of the information published clearly could be biased. To limit this problem, we cross-checked the data with similar information published in another industry journal and observed no digression. Second, our sample size represents another limitation, though it is in line with most other empirical research using franchise directories.

In addition, some key findings warrant further attention. It would be interesting to conduct a study that analyzes whether the entrepreneurial skills expected among future franchisees are actually those they exhibit once they have joined the system. Very few of the franchisors we met test their potential franchisees formally to 
determine their entrepreneurial skills. Nor does much research investigate the determinants and consequences of selecting an entrepreneurial profile. Recent work by Dada et al. (2012) deserves attention in this perspective; they suggest a contingency perspective and also recommend studying how the type of contracting (formal/relational) used by a franchisor might define the attractive contractual conditions for different profiles. Therefore, further research could study what profile performs best, which profile behaves opportunistically, and how contractual arrangements might help attract and retain the best franchisees.

\section{AUTHOR INFORMATION}

Jacques Boulay is Professor of Marketing and Associate Dean for research and school developments at ESSCA School of Management, France. Before joining ESSCA, he worked as a marketing and sales manager and as a senior consultant in the field of retailing with a focus on change management. He earned his Ph.D. in Management Science from the University of Paris Dauphine. His research interest relates primarily to the fields of franchising and retail marketing. His research appears in national and international marketing and management journals. jacques.boulay@essca.fr (Corresponding author)

Valentina Stan is Associate Professor of Marketing at ESSCA School of Management, France. She earned her $\mathrm{Ph} . D$. in Management Science from University of Paris Conservatoire National des Arts et Métiers. Her research interest relates primarily to the fields of franchising, consumer satisfaction and loyalty and structural equations models. valentina.stan@essca.fr

\section{REFERENCES}

1. Anderson, R.L., Condon, C., \& Dunkelberg, J. (1992). Are franchisees "real" entrepreneurs? Journal of Business and Entrepreneurship, 4(1) 97-105.

2. Bowen, G.A. (2008). Naturalistic inquiry and the saturation concept: a research note. Qualitative Research, 8(1) $137-152$.

3. Bradach, J.L. (1998). Franchise organizations. Boston, Mass., Harvard Business School Press.

4. Brookes, M., \& Altinay, L. (2011). Franchise partner selection: perspectives of franchisors and franchisees. The Journal of Services Marketing, 25(5) 336-348.

5. Chandler, G., \& Hanks, S.H. (1994). Market attractiveness, resource-based capabilities, venture strategies and venture performance. Journal of Business Venturing, 9(4) 331-349.

6. China Chain stores and Franchise association (2011), http://www.chinaretail.org, accessed December 10, 2011.

7. Clarkin, J.E., \& Rosa P.J. (2005). Entrepreneurial teams within franchise firms. International Small Business Journal, 23(3) 303-334.

8. Cochet, O., Dormann, J., \& Ehrmann T. (2008). Capitalizing on franchisee autonomy: relational forms of governance as controls in idiosyncratic franchise dyads. Journal of Small Business Management, 46(1) 5072.

9. Dada, O., \& Watson, A. (2013). Entrepreneurial orientation and the franchise system: organizational antecedents and performance outcomes. European Journal of Marketing, 47 (5/6).

10. Dada, O., Watson, A., \& Kirby, D. (2011). Toward a model of franchisee entrepreneurship. International Small Business Journal, 30(5), 559-583.

11. Dahlstrom, R., \& Nygaard, A. (1999). An empirical investigation of ex post transaction costs in franchised distribution channel. Journal of Marketing Research, 36 (May) 160-170.

12. Dant, R.P., Perrigot, R., \& Cliquet, G. (2010). A cross cultural comparison of the plural forms in franchise networks: United States, France and Brazil. Journal of Small Business Management, 46(2) 286-311.

13. Dant R.P. (2008). A futuristic research agenda for the field of franchising. Journal of Small Business Management, 46(1) 91-98.

14. Dant, R.P., \& Gundlach, G.T. (1999). The challenge of autonomy and dependence in franchised channels of distribution. Journal of Business Venturing, 14, 35-68.

15. Edens, F.N., Self, D.R., \& Grider, D.T. (1976). Franchisors describe the ideal franchisee. Journal of Small Business Management, 14(3) 39-47. 
16. Fenwick, G.D., \& Strombom, M. (1998). The determinants of franchise performance: an empirical investigation. International Small Business Journal, 16(4) 28-45.

17. Garg, V.K., Rasheed, A.A., \& Priem, R.L. (2005). Explaining franchisor's choices of organization forms within franchise systems. Strategic Organization, 3(2) 185-217.

18. Gauzente, C. (2002). Using qualitative methods in franchise research: an application in understanding the franchised entrepreneur's motivations. Forum: Qualitative Social Research, 3(1) art. 20.

19. Greene J.C., Caracelli, V.J., \& Graham, W.F. (1989). Toward a conceptual framework for mixed-method evaluation designs. Educational Evaluation and Policy Analysis, 11(3) 255-274.

20. Grünhagen, M., \& Mittelstaedt, R.A. (2005). Entrepreneurs or investors: Do multi-unit franchisees have different philosophical orientations? Journal of Small Business Management, 43(3) 207-225.

21. Guilloux, V., Gauzente, C., Kalika, M., \& Dubost, N. (2004). How France's potential franchisees reach their decisions: a comparison with franchiser's perceptions. Journal of Small Business Management, 42(2) 218-224.

22. Hing, N. (1995). Franchisee satisfaction: contributors and consequences. Journal of Small Business Management, 33(2) 12-25.

23. Hussain D. and Winsperger J. (2011), Multi-unit franchising: a comparative case analysis, The Journal of Applied Business Research, 27 (1), 103-111.

24. Jambulingam, T., \& Nevin, J.R. (1999). Influence of franchisee selection criteria on outcomes desired by the franchisor. Journal of Business Venturing, 14(4) 363-395.

25. Kaufmann, P.J., \& Dant, R.P. (1998). Franchising and the domain of entrepreneurship research. Journal of Business Venturing, 14(1) 5-16.

26. Kaufmann, P.J., \& Eroglu, S. (1999). Standardization versus adaptation in business format franchising. Journal of Business Venturing, 14(1) 69-85.

27. Ketchen, D.J., Short, J.C., \& Combs, J.G. (2011). Is franchising entrepreneurship? Yes, no, and maybe so. Entrepreneurship and practice, 35(3) 583-593.

28. Knight, R.M. (1986). Franchising from the franchisor and franchisee points of view. Journal of Small Business Management, July, 87-15.

29. Knight, R.M. (1984). The independence of the franchisee entrepreneur. Journal of Small Business Management, 22(2) 53-61.

30. Lafontaine, F., \& Raynaud, E. (2002). The role of residual claims and self-enforcement in franchise contracting. Working Paper, NBER 8868.

31. Lindblom, A., Olkkonen, R., \& Mitronen, L. (2008). Cognitive styles of contractually independent entrepreneurs: a survey study. International Journal of Retail and Distribution Management, 36(6) 518532.

32. Lumpkin, G.T., \& Dess, G.G. (1996). Clarifying the entrepreneurial orientation construct and linking it to performance. Academy of Management Review, 21(1) 135-172.

33. Malhotra, N. (2006). Marketing Research: an applied orientation. $5^{\text {th }}$ edition, Prentice Hall.

34. Mesconi, T.S., \& Montanari, J.R. (1981). The personalities of independent and franchise entrepreneurs. An empirical analysis of concepts. Journal of Enterprise Management, 3(2) 149-159.

35. Miles, M.B., \& Huberman, A.L. (1994). Qualitative data analysis. Sage.

36. Paswan, A., \& Johns, R. (2007). Is a franchisee entrepreneur or employee? An exploratory investigation of perceptions about being a franchisee. $21^{\text {st }}$ International Society of Franchising, Las Vegas, 24-25 February.

37. Perrigot, R., Cliquet, G., \& Piot-Lepetit, I. (2009). Plural form chain and efficiency: Insights from the French hotel chains and the DEA methodology. European Management Journal, 27(4) 268-280.

38. Perrigot, R. (2006). Services vs retail chains: are there any differences? Evidence from the French franchising industry. International Journal of Retail and Distribution Management, 34(12) 918-930.

39. Rossman, G.B., \& Wilson, B.L. (1994). Numbers and words revisited: Being "shamelessly eclectic. Quality \& Quantity, 28(3) 315-327.

40. Shane, S., \& Foo, M.D. (1999). New firm survival: institutional explanations for new franchisor mortality. Management Science, 45(2) 142-159.

41. Smith, N.R. (1967). The entrepreneur and his firm: the relationship between type of man and type of company. Bureau of business and economic research, Michigan State University.

42. Stanworth, J. (1995). The franchise relationship: entrepreneurship or dependence? Journal of Marketing Channels, 4(1-2) 161-176. 
43. Tuunanen, M., \& Hyrsky, K. (2001). Entrepreneurial paradoxes in business format franchising: an empirical survey of Finnish franchisees. International Small Business Journal, 19(4) 47-62.

44. Vaishnav, T., \& Altinay, L. (2009). The franchise partner selection process and implications for India. Worldwide Hospitality and Tourism Themes, 1(1) 52-65.

45. Waysman, M., \& Savaya, R. (1997). Mixed method evaluation: a case study. American Journal of Evaluation, 18(3) 227-237.

46. Weaven, S., \& Frazer, L. (2007). Mature franchise systems use MUF to leverage learning economies and sustain system wide growth. Asia-Pacific Journal of Marketing and Logistics, 19(2) 107-126.

47. Welsh, D.H.B., Alon, I., \& Falbe, C.M. (2006). An examination of international retail franchising in emerging markets. Journal of Small Business Management, 44(1) 130-149.

48. Williams, D.L. (1998). Why do entrepreneurs become franchisees? An empirical analysis of organizational choice. Journal of Business Venturing, 14(1) 103-124.

49. Withane, S. (1991). Franchising and franchisee behaviour: an examination of opinions, personal characteristics, and motives of Canadian franchisee entrepreneurs. Journal of Small Business Management, 29(1) 22-29. 